\title{
The Implementation of Budget Model Program in Forming the Primary School Operational Assistance Budgets
}

\author{
Maman Rusmana \\ STKIP Garut \\ mmn_c16@yahoo.com
}

\author{
N. Leni Sri Mulyani \\ STKIP Garut
}

\begin{abstract}
School operational assistance is one of the government assistance programs given to the school to reach the compulsory education completion. This study aimed to determine the effectiveness of such assistance to the equitable teaching learning process. The research method used was descriptive analysis to analyze the impact of policies and methods of Research and Development $(R \& D)$ in order to implement the model in policy development. The results of this study were expected to find the impact of policies and can solve problems in order to improve future policy.
\end{abstract}

Keywords - School Operational Assistance, Effectiveness, Equitable

\section{INTRODUCTION}

The Indonesian Law No. 20 Year 2003 on National Education System includes funding for education in Article 11, paragraph 2 in which stated that Government and Local Government must ensure the availability of funds for the provision of education dedicated to every citizen aged seven to fifteen years [1]. School Operational Assistance Program is one programs on basic educational funding, this to assure that school-age children, especially 7-15 years can go to school, particularly designed for children from poor families, thus they will not need to think more about the school fees. Regardless where the source of funds for education from and what system of budgeting was being used, the criterion is focusing on the impact of these costs to cater the services of the equitable learning process at each of educational institution on their learners.

The determination of the amount of school operational assistance funds on education units that apply currently based on Ministry of Education Regulation Number 69 Year 2009

Regarding to Non Personnel Standard Operating Costs, the School Operational Assistance (BOS) was calculated IDR 580,000 for each student in 2009 per year, whereas for the financial year 2015 it turns into IDR 800,000 [2]. The amount determination of the budget each year is described as follows.

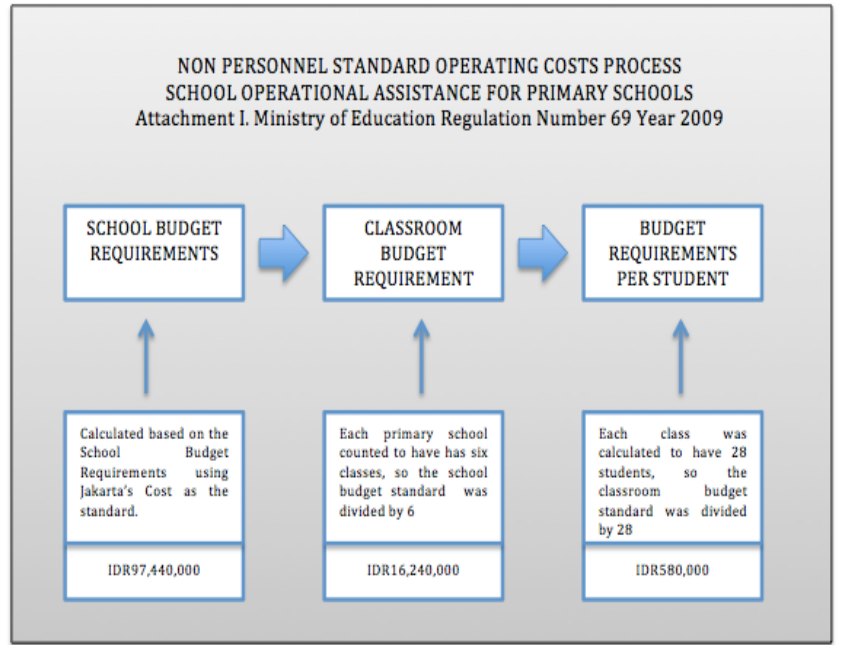

Figure 1. System Determination Magnitude of School Operational Assistance at School

These calculations could presumably correct if the number of students in each school were equal, but what really happened was every school has a disproportionately number of students in which the activity components in each school were relatively the same. This condition was in line with the fact reveals that there is no single approach considered as the best school funding for financing all schools as for the differences of condition [3] [4] [5]. So, in this case it is impossible to calculate the school budget prorated based on national calculations. Budget calculations should be based on the complexity of the activities within the organization/institution in educational institutions in which school is one of the examples. The calculation can be described as follows. 


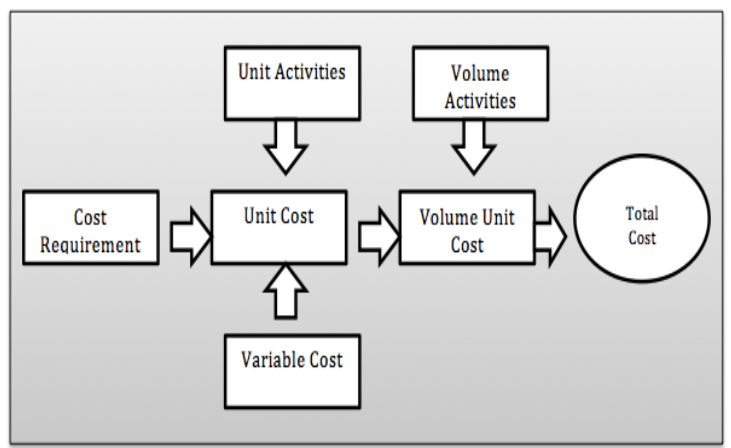

Figure. 2. Determination of the School Budget Formulation System Based On Complexity of Activities

Reference [4] defines the financing of education in an effort to raise funds to finance the operations in the education sector. There are two key dimensions of school funding model, namely; the cost allocation dimension and the dimension of income (revenue). The cost allocation dimension associated with the target populations adapted to programs, services and availability of facilities. We can see from the above opinion that the determination of the budget in state institutions, especially at school must be adapted to the type of program and the greater of the volume contained in each program.

The results of this research provide the strategy determination information of the amount and flow budgeting School Operational Aid implemented by the school today, and also the information of model system application program which is used as an experiment by the researcher, which will show the shortcomings of the policies implemented to date, and excess the model program presented by the researcher.

\section{RESEARCH METHODOLOGY}

This research was using the Research and Development method. The control information was based on the policies, which were applied recently, and the experiment information was gain from the model, which was applied by the researcher. Control information for determining the amount of the budget obtained through a survey conducted by the descriptive analysis, which analyzes the data to obtain information in connection with the determination of the amount of the policy and the operational costs budgeting flow at primary school level. Two stages were done in obtaining such information. The first stage was analyzing the document, which analyzes the policies or regulations issued by the Government today and the data state schools. The second stage, research conducted by survey sampling technique random sampling through the system area. The population includes primary school in Garut Municipality with the total of 42 districts by taking a sample of 11 districts, from each district was taken 8-12 school units with general total of 132 school units. The technique used in obtaining the data/information from respondents using questionnaires and interviews. The main respondents were the principals, while the supporting respondents were the school superintendent and Head of the Regional Technical Implementation Unit of Primary Education at the district level. Elementary School who were targeted were divided into two groups, namely Category 1 was a school that has a number of students who do not meet the standards with only 167 people and Category 2 was groups of primary schools that meet the standard minimum of students. The composition of students in the sample schools is as follows:

Table 1. Primary School Groups Category

\begin{tabular}{|c|c|c|c|}
\hline No & $\begin{array}{c}\text { School } \\
\text { category }\end{array}$ & $\begin{array}{c}\text { Student } \\
\text { number }\end{array}$ & $\begin{array}{c}\text { Total primary } \\
\text { School }\end{array}$ \\
\hline 1 & Category 1 & $<168$ pupil & 47 unit \\
\hline 2 & Category 2 & 168 -up & 85 unit \\
\hline 3 & Total & & 132 unit \\
\hline
\end{tabular}

From each of the categories, the researcher viewed the average of service given to service learning in the relation with the operational funds received.

In analyzing the budgeting process flow, the information obtained from the School Budget document, as all schools implemented the same model of process flow, the researchers took a sample of data/information from three primary schools that have different number of students which was categorized as below the standard, meets the standard and above standard.

Using the rubric of performance assessment to view the extent of the budget allocation preparation by using the orientation Budgeting System programming in school did the research development. In conducting this research two stages were taken. The first stage, research was giving budget preparation training to the Principal/teacher. This training was also proposed discussions among participants to discuss the variables that should be used in determining the amount of budget related with the components of the programs listed in the school operational assistance guidebook. The second phase, the researcher analyzed the flow of the preparation of school programs better known as School Activity, Budget and Expenditure Plan; which was the budget and the global activities of the school budget and specific activities, namely the budget and non personnel budget activity which were part of the school's Budget and Expenditure Plan. This was funded from the School's Operational Assistance Fund of the Central Government, the components of its use has been determined in accordance with the established fiscal policy each year.

\section{RESEARCH FINDINGS AND DISCUSSION}

From the amount of budget policy determination in each school by using a variable number of students, using a variable number of students captured the gap between groups of Category 1 and Category 2 in providing services in the form of budget amounts for each component to meet the needs of each component. From the 13 components of the activities that should be funded by the school operational assistance, gap were found in six components; namely school maintenance parts, labor payment/temporary teacher, 
extra curricular activities, teacher professional development, aid poor students, and the purchase of new goods. The standard requirements achievement for each component is shown in Table 2 and Figure 3.

Table 2. Service Learning Components Target Achievement

\begin{tabular}{|c|c|c|c|}
\hline \multirow[t]{2}{*}{ NO } & \multirow[t]{2}{*}{ School Operational Assistance Component } & \multicolumn{2}{|c|}{$\begin{array}{c}\text { Program Achievements } \\
(\%)\end{array}$} \\
\hline & & Category 1 & Category 2 \\
\hline 1 & Library Development & 80 & 95 \\
\hline 2 & New Student Acceptance & 100 & 100 \\
\hline 3 & Co Curricular Activities & 50 & 90 \\
\hline 4 & School Test/Examination & 75 & 100 \\
\hline 5 & Activity Learning Process (consumables goods) & 90 & 100 \\
\hline 6 & Power Subscription Services & 100 & 100 \\
\hline 7 & School Building Maintenance & 50 & 100 \\
\hline 8 & Honorarium Payment for Labor/Temporary Teachers & 45 & 100 \\
\hline 9 & Teachers Professional Development & 60 & 80 \\
\hline 10 & Students' Aid & 30 & 80 \\
\hline 11 & School Operational Assistance Management Fee & 100 & 100 \\
\hline 12 & Computer Maintenance & 75 & 90 \\
\hline 13 & $\begin{array}{l}\text { The utilization of the remaining funds } \\
\text { (new stuff purchasing) }\end{array}$ & 10 & 90 \\
\hline & The average target achievement & $66.54 \%$ & $94.23 \%$ \\
\hline
\end{tabular}

Further details shown us the graph below:

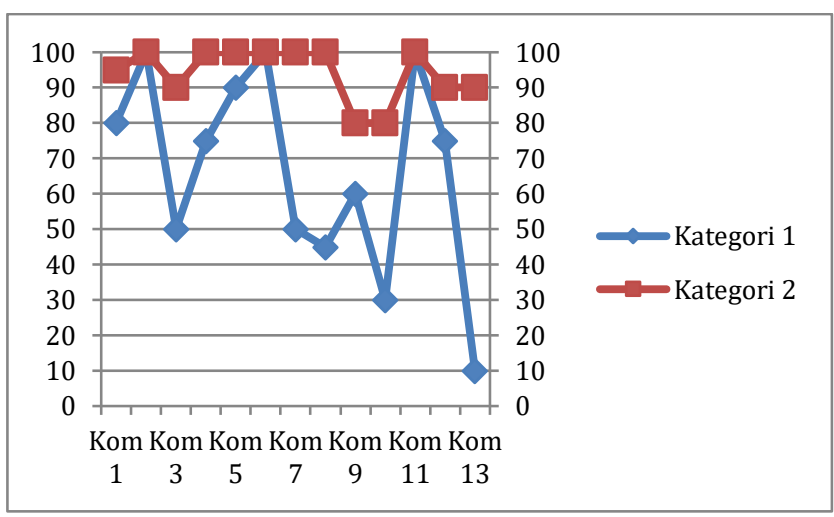

Figure 3. Graph Difference Between Educational Services Category 1 and Category 2

It revealed that the overall service level difference between the primary school category 1 and 2 was $66.54 \%$ with $94.23 \%$ fulfillment of the standard requirement.

Further information was taken from the budgeting flow implemented by schools based on School Operational Assistance handbook, which was initiated by compiling Budget and Activity Schools Plan (RKAS) overall in a form of School Activity and Expenditure Budget Plan $(R A P B S)$. Then, the researcher counted and analyzed which activities budgets were included in the school operational assistance component and which were part of the school Budget Plan sourced from funds received by schools or types of activities. Below is a picture of the budget school operational assistance process flow:

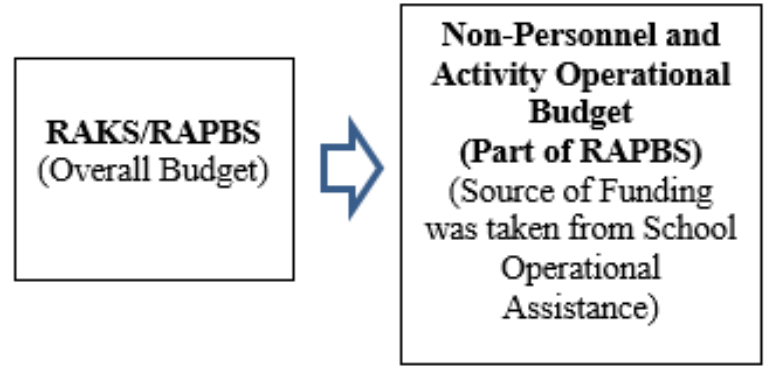

Figure. 4 Budgeting Scheme Sourced from School Operational Assistance Funds from Global to the Partial Parts

From the above scheme, the distribution of School Operational Assistance funds to the components were described as follows:

Table. 3. The Distribution of School Operational Assistance Funds Based on The Budgetary Flow Process Handbook

\begin{tabular}{|c|l|c|}
\hline No & \multicolumn{1}{|c|}{ School Operational Assistance Components } & $\begin{array}{c}\text { Percentage } \\
\text { (\%) }\end{array}$ \\
\hline 1 & Library Development & 05,52 \\
\hline 2 & New Student Acceptance Activity & 01,48 \\
\hline 3 & Curricular and Co Curricular Activities & 12,58 \\
\hline 4 & School Test/Examination & 19,40 \\
\hline 5 & Learning Process (consumables goods) & 15,25 \\
\hline 6 & Power Subscription Services & 02,84 \\
\hline 7 & School Building Maintenance and Sanitation & 07,19 \\
\hline 8 & Honorarium Payment for Labor/Temporary Teachers & 19,61 \\
\hline 9 & Teachers Professional Development & 06,55 \\
\hline 10 & Students' Aid & 00,27 \\
\hline 11 & School Operational Assistance Management Fee & 04,03 \\
\hline 12 & Computer Procurement \& Maintenance & 02,41 \\
\hline 13 & $\begin{array}{l}\text { The utilization of the remaining funds should component 1 - 12 has } \\
\text { been fulfilled by School Operational Assistance }\end{array}$ & 02,87 \\
\hline \multicolumn{2}{|c|}{ Total } & 100,00 \\
\hline
\end{tabular}

The Preparation Flow of school operational assistance funds, which was applied starting from the partial budget (part of RAKS/RAPBS), specifically on preparing the budget and activities components; in which the funds have been provided by the school operational assistance handbook. Then all of them were included into School Activity Budget Plan along with the sources and the use of funds. The brief plot was described in the figure below:

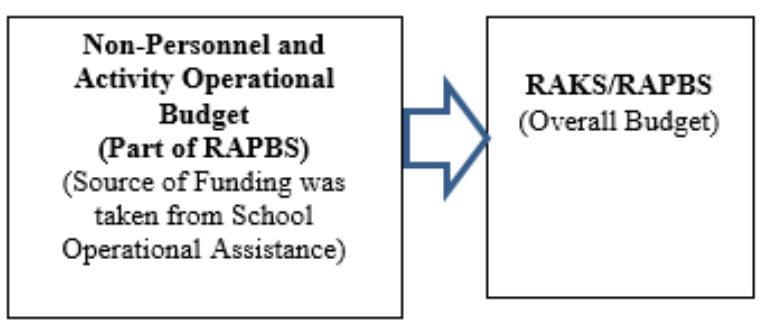

Figure.5. Budgeting Scheme Sourced from School Operational Assistance Funds From Global to the Partial Parts 
With that budget preparation process flow, the use of school operational assistance funds were distributed to its components as follows:

Table 4. The Distribution of School Operational Assistance Funds on Its Components Based on The Budgetary Partial to Global Flow

\begin{tabular}{|c|l|c|}
\hline No & \multicolumn{1}{|c|}{ School Operational Assistance Components } & $\begin{array}{c}\text { Percentage } \\
(\%)\end{array}$ \\
\hline 1 & Library Development & 05,52 \\
\hline 2 & New Student Acceptance Activity & 01,48 \\
\hline 3 & Curricular and Co Curricular Activities & 08,58 \\
\hline 4 & School Test/Examination & 10,01 \\
\hline 5 & Learning Process (consumables goods) & 30,25 \\
\hline 6 & Power Subscription Services & 02,84 \\
\hline 7 & School Building Maintenance and Sanitation & 12,19 \\
\hline 8 & Honorarium Payment for Labor/Temporary Teachers & 15,00 \\
\hline 9 & Teachers Professional Development & 06,55 \\
\hline 10 & Students' Aid & 00,27 \\
\hline 11 & School Operational Assistance Management Fee & 02,03 \\
\hline 12 & Computer Procurement \& Maintenance & 02,41 \\
\hline 13 & $\begin{array}{l}\text { The utilization of the remaining funds should component 1 - } 12 \\
\text { has been fulfilled by School Operational Assistance }\end{array}$ & 02,87 \\
\hline \multicolumn{2}{|l|}{ Total } \\
\hline
\end{tabular}

School Operational Assistance is basically given by the government to assist the school in serving the students; in which being implemented to support the learning process, thus every school and students should get the same service. This is coherence with the government policy through the Ministry of Education Regulation Number 69 Year 2009 regarding to the Non Personnel Standard Operating Costs, who set the standard of School Operational Assistance based on the number of students in the schools. The amount of assistance was based on the number of students and also correlated with minimum service standards of educational services, whereas the minimum service standards for school funding was defined in the calculation of each class consisted of 28 pupils. The result of this research proved the statement, that on primary school category 2 , schools can serve the learning needs of an average $94.23 \%$.

On the other hand, the number of primary school learners below the standard of less than 168 people, then these deficiencies affect the reduced revenue budget of the school. Reduced revenue sources affect the learning services it proved to service learning at the primary school category 1 service learning only reached an average of $66.54 \%$. Cost is one of the resources that directly support the effectiveness and efficiency of education management [6]. Besides, it proves that the school operational assistance in the educational unit can not be determined, only one variable is the number of students, but is also influenced by other variables based on the type and volume of activities. In school funding and no single approach is best for the financing of all schools because each school is different conditions [5]. So, in this case it is impossible to calculate the school budget prorated based on national calculations. [8] [9]

The calculation of the amount of funds required can be calculated based on variables associated with those components and standard activities on the needs of each school, as shown in the table below:

Table 5. Formulation Requirement Standard of School Operating Costs

\begin{tabular}{|c|c|c|c|c|}
\hline No & $\begin{array}{c}\text { Calculation } \\
\text { Based }\end{array}$ & $\begin{array}{c}\text { Activities } \\
\text { Component }\end{array}$ & $\begin{array}{c}\text { Requirement } \\
\text { Standard }\end{array}$ & $\begin{array}{c}\text { Cost } \\
\text { Standard }\end{array}$ \\
\hline 1 & School Unit & $\begin{array}{ll}\text { - } & \text { Co Curricular } \\
\text { - } & \text { Power } \\
& \text { Subscription } \\
& \text { Services } \\
\text { - } & \text { Teachers } \\
& \text { Professional } \\
& \text { Development } \\
\text { - } & \text { School } \\
& \text { Operational } \\
\text { Assistance } \\
\text { Management } \\
\text { Fee }\end{array}$ & $\begin{array}{l}\text { Number of } \\
\text { Activities*) } \\
\text { Usage Amount } \\
\left.{ }^{*}\right) \\
6 \text { Xnumber of } \\
\text { subjects } \\
\text { The average } \\
\text { requirement }\end{array}$ & $\begin{array}{l}\text { Per activity } \\
\text { Per activity } \\
\text { Per School }\end{array}$ \\
\hline 2 & $\begin{array}{l}\text { Per } \\
\text { Student }\end{array}$ & 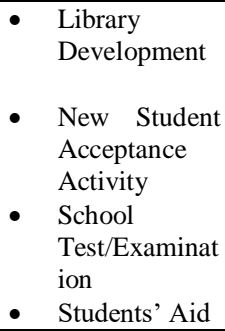 & $\begin{array}{l}10 \% \text { of total } \\
\text { students } \\
1 / 6 \text { of total } \\
\text { students } \\
\text { Total Students } \\
10 \% \text { of total } \\
\text { students }\end{array}$ & $\begin{array}{l}\text { Book Price } \\
\text { Per - student } \\
\text { Per - student } \\
\text { Per - student }\end{array}$ \\
\hline 3 & $\begin{array}{l}\text { Per } \quad- \\
\text { Classroom }\end{array}$ & $\begin{array}{l}\text { School Building } \\
\text { Maintenance and } \\
\text { Sanitation }\end{array}$ & $\begin{array}{l}\text { Total number } \\
\text { of classroom }\end{array}$ & $\begin{array}{l}\text { Per } \\
\text { classroom }\end{array}$ \\
\hline 4 & $\begin{array}{ll}\text { Per } & - \\
\text { Learning } & \\
\text { Group } & \\
\end{array}$ & $\begin{array}{l}\text { Learning Process } \\
\text { (consumables } \\
\text { goods) }\end{array}$ & $\begin{array}{l}\text { Total learning } \\
\text { Groups }\end{array}$ & Per-Group \\
\hline 5 & $\begin{array}{l}\text { Per } \\
\text { personnel }\end{array}$ & $\begin{array}{l}\text { Honorarium } \\
\text { Payment for } \\
\text { Labor/Temporary } \\
\text { Teachers }\end{array}$ & Total person $\left.{ }^{*}\right)$ & Per-person \\
\hline
\end{tabular}

${ }^{*}$ Restrictions at any educational institution/school applied

In the basic calculation, there will be component in which the number of activities is being limited up to the minimum standard requirements. For example, the need for teachers in primary schools is at least having 6 personnel. If the existed full-time teachers were three people, it means that the school needs for maximum 3 additional teachers. The components of extra-curricular and Power Subscription Services will depend on the policy. For the component of teachers' professional development will be highly depend on the number of subjects and grade (whereas there are six levels of classes in primary schools). As for the need of School Operational Assistance Management Fee and Stationery Supply were calculated based on the average needs in advance and percentage of funds received. For the component of libraries, was being calculated from $10 \%$ in terms of the degree of books usage and damaged, while the calculation of poor children (students' aid) in each school will be depending on the policy.

The flow of budgeting process which was preceded by the drafting of the Budget concerning School's revenue 
inclusive all sources of funds, as well as all activities within the scope of the school. This research revealed that there were some activities; which actually should not be funded from the school operational assistance. This finding appeared especially in some schools; which only received operational funds without any other extra funding. Thus, there was expenditure out of the intended components or exceeds the percentage allocation of provisions. For example, the component of honorarium for temporarily staff as written in the handbook maximum on $15 \%$ of the funds, but in reality it reached $19.6 \%$. Then, the component of consumable items, mostly for organizing the learning process only reaches $15.25 \%$, although this component does not have any limitation, but it is considered as irrational to charge the regular learning process; which was carried out every day, lower than the portion of the costs for the evaluation, with $19.40 \%$ of the funds.

\section{CONCLUSION}

The determination of the amount of school operational assistance funds based on the number of learners in providing the service of learning can lead to inequitable, because the variables that determine the fulfillment of the budget is not only determined by the number of students, but there are also other variables related to the type and volume of activities that exist in any educational institution. If students become the focus in determining the amount of fees in the educational unit, then there should not only be analyzed from the individual indicator/variable, but also consider the learning group and classroom itself. Eventually, it will have an impact on the cost of other learning needs.

Currently, the number of students in each educational unit was varied; there is still a gap between the education units. It is influenced by the geographical factors (remote) and/or because of the limited economic resources. Thus, with the current conditions, the determination of educational unit amount of the budget based on the number of students has not been able to provide equitable learning services.

To avoid misuse/misapplication of funds utilization in the budgeting flow - as for a separate budget should be accounted for separately, then Activity Budget Plan of School Operational Assistance should be made separately. But it is still become a part of the budget and other school activities, in which subsequently incorporated into the Budget and School Activity as a whole component thoroughly in a form of the School Budget and Revenue Plan.

\section{REFERENCE}

[1] Undang -Undang No. 20 Tahun 2003 Tentang Sistem Pendidikan Nasional.

[2] Eric A. Hanushek. 1997. Assessing the Effects of School Resources on Student Performance: An Update. SAGE Journal EDUCATIONAL EVALUATION AND POLICY ANALYSIS vol. 19 no. 2 141-164. [Online] Downloaded http://epa.sagepub.com/content/19/2/141.short
[3] Duflo, Esther., Dupas, Pascaline., \& Kremer, Michael. 2015. School governance, teacher incentives, and pupil-teacher ratios: Experimental evidence from Kenyan primary schools. Journal of Public Economics Volume 123 pp $92-110$. [Online] Downloaded from

http://www.sciencedirect.com/science/article/pii/S00472727140024 $\underline{12}$.

[4] Dirjen Manajemen Dikdasmen Kementrian Pendidikan Nasional, 2009,Pedoman Pengelolaan Bantuan Operasional Sekolah (BOS), Jakarta.

[5] Fattah, N. (2008), Pembiayaan Pendidikan Landasan Teori dan Studi Empiris, Jurnal Pendidikan Dasar. Nomor.9 April 2008.

[6] Bastian, 1/(2006), Akuntansi Pendidikan, Jakarta, Erlangga

[7] E. Mulyasa, Manajemen Berbasis Sekofah ${ }^{\wedge}$ Bandung: Remaja Rosdakarya, 2002

[8] Odden, Alan., Picus, Lawrence O., \& Griffith, Michael. 2016. Using the Evidence - Based Method to Identify Adequate Spending Levels for Vermont Schools. [Online] Downloaded from http://www.leg.state.vt.us/jfo/education/adequacy/VT\%20EB\%20Ana 1ysis\%2020.1.pdf

[9] Bourdeaux, Carolyn., Warner, Nicholas. 2015. School Districts' Expenditure Responses to Federal Stimulus Funds. Journal of Education Finance Volume 41, Number 1, Summer 2015 pp. 30 - 47. [Online] Downloaded from https://muse.jhu.edu/article/596200/summary 